\title{
Developmental Aspects of Renal $\beta$-Amino Acid Transport I. Ontogeny of Taurine Reabsorption and Accumulation in Rat Renal Cortex
}

\author{
RUSSELL W. CHESNEY (56) AND DIANE K. JAX \\ Pediatric Renal Disease Laboratory, Department of Pediatrics, The University of Wisconsin Center for Health \\ Sciences, Madison, Wisconsin USA
}

\section{Summary}

Newborn Sprague-Dawley rat pups were found to have reduced net tubular reclamation of the $\beta$-amino acid taurine in vivo. The reabsorption of this compound increased between the 2 nd and 4 th week of life and the excreted taurine fell despite a rise in glomerular filtration rate indicative of increased transport with maturation.

Kidney cortex in vivo accumulated taurine from plasma against a large chemical gradient. Newborn cortex slices in vitro accumulated taurine to higher levels at steady state at $<0.4 \mathrm{mM}$, but uptake was less efficient at higher taurine concentrations. Further metabolism of taurine by cortex slices was not found at any age. Accumulation in adult and newborn cortex was greatest at 10-15 $\mathrm{mEq} /$ liter $\mathrm{K}$ in the external medium. Slices from younger animals had slightly higher pH optima for uptake and temperature elevation increases uptake more in neonatal than in adult kidney.

\section{Speculation}

If the newborn rat is in part dependent on the transfer of taurine from mother to pup via milk, the process of weaning may require greater renal tubular reabsorption in order to maintain tissue and plasma pools of taurine. The improved reabsorption of taurine found in 4-week-old and adult animals may reflect maturational changes brought about by the reduction in dietary taurine (and other sulfur containing amino acids) after weaning.

Taurine (2-aminoethanesulfonic acid), the amino acid characteristic of rodent urine, functions as a neurotransmitter in many mammalian species, including man $(12,17,34)$. This sulfur containing $\beta$-amino compound is lost from the body predominantly by urinary excretion because its metabolism to isotheonic acid is limited. The maintenence of tissue levels of taurine may depend, in part, on the maturation of the renal transport system for $\beta$ amino acids (16). Taurine is one of the more prevalent amino acids in human newborn urine; its excretion being greater in full term infants than in prematures (18). Urinary taurine excretion falls over the first months of life and the tubular reabsorption reaches $96-99 \%$ of the filtered load. Reabsorption is actually more efficient during the first 60 days of life than later when it falls to $90-95 \%$ (18). Taurine excretion in neonates and infants is reduced further if they are fed a cow's milk or synthetic casein-containing formula; the finding of reduced plasma taurine levels in these infants implies dependence on a dietary source of taurine and inefficient taurine synthesis $(15,34)$. It is plausible that the decline in urinary taurine excretion over the first wk of life may represent decreased dietary availability with "switching on" of renal tubular transport mechanisms to maintain body taurine pool size. Despite evidence that breast milk is a dietary source of taurine in the weanling rat, several studies have suggested fully developed taurine synthetic capacity in the neonatal rat in contrast to the situation in man $(34,35)$.

The renal uptake of taurine both in vivo and in vitro has been defined in adult mouse (10) and in adult rat kidney cortex $(7,9)$. Endogenous clearance of taurine in rat may be as high as $40 \%$ (19), but most studies utilizing free flow micropuncture (13) or continuous microperfusion (11) have consistently found a clearance of $5 \%$ of filtered load, a value akin to that found in $\mathrm{A} / \mathrm{J}$ mouse (10). The taurine reabsorptive system, in contrast to net reclamation for most $\alpha$-amino acids, demonstrates a high affinity, but low capacity for uptake; thus, reabsorption of only $90-95 \%$ of filtered load has been found $(9,11,30)$. Uptake by cortex slices, indicative of antiluminal membrane transport $(41,42)$, took place by at least two taurine carriers in both mouse and rat $(7,9,10)$. Each site was sodium-dependent, required aerobic metabolism, and, of all amino acids tested, only $\beta$-amino acids, such as $\beta$ alanine, prevented taurine uptake in a competitive fashion $(9,10$, 16). Glutathione oxidation inhibited taurine accumulation by the first (low $\mathrm{Km}$, high affinity) transport system possibly by enhanced taurine efflux $(7,9)$. The pattern of taurine excretion and the tissue levels of this amino acid over the first few weeks of life should be informative relative to the ontogeny of renal transport mechanisms, particularly because amino acid hyperexcretion is characteristic of the early postnatal period in man and other mammals $(1,30)$. In this paper, the authors discuss the development of the in vivo taurine renal transport system during the first month of life. Parallel studies defining the accumulation of taurine by cortex slices from animals of varying ages will examine the influence of time, temperature, $\mathrm{pH}$, and metabolism of taurine.

\section{MATERIALS AND METHODS}

\section{ANIMALS}

Sprague Dawley rats $(43,44)$ were fed ad libitum on Lab-Blox chow and water. Adult rats, $220-300 \mathrm{~g}$, newborn pups ( $<36 \mathrm{hr}$ of age), and pups aged 14 and 28 days were used.

\section{IN VIVO STUDIES}

Urine was collected in Gelman metabolic cages for 6-24 hr with care to catch all stool on wire mesh (44). Animals were fasted during the collection period. One adult animal was utilized per collection; two 4-wk-old and four to five 2-wk-old pups were used. The urines from each age group was pooled. Ether inhalation before killing led to complete bladder evacuation in all but newborn animals where bladder puncture with a 25 gauge needle 
and gentle syringe suction was used to collect urine. Urine was filtered, collected in clean tared flasks, and frozen immediately at $-20^{\circ} \mathrm{C}$. Unclotted arterial blood was collected through a 22 or 25 gauge needle into heparinized syringes from a puncture at the bifurcation of the iliac arteries; this technique provides free flowing blood in quantities up to $10 \mathrm{ml}$ in an adult animal. Plasma was immediately separated with care not to stir the buffy coat, because platelets and leukocytes contain high levels of taurine (28). Plasma was immediately diluted with sulfosalicylic acid (3\% W/V) and centrifuged at $10,000 \mathrm{rpm}$. The protein-free supernate was recovered and stored at $-20^{\circ} \mathrm{C}$. This method has been shown to yield complete recovery of taurine (28).

Kidney cortex was removed, blotted on Whatman \#1 paper, weighted, and homogenized manually in $6 \%$ perchloric acid using a Potter-Elvehjem glass homogenizer and a Teflon plunger. The protein-free supernate obtained after centrifugation at $10,000 \times g$ for $10 \mathrm{~min}$ was stored at $-20^{\circ} \mathrm{C}(45)$. Tissue used was also sliced in a modified Stadie-Riggs microtome, as previously described (7), before weighing and homogenization.

Timed urine and plasma collection allows estimation of the renal clearance of taurine, because a simultaneous endogenous creatinine clearance was performed in 2-wk, 4-wk, and adult animals. Standard equations allowed calculation of filtered and excreted taurine and its reclaimed fraction. Because timed collections in newborn pups was not possible, no clearance data were obtained.

\section{IN VITRO STUDIES}

Thin cortex slices were prepared from animals of all ages and incubated as previously described $(7,9,20,25)$. The average slice weight is $4.98 \pm 0.5 \mathrm{mg}$ (mean $\pm \mathrm{SD}, n=380$ ) and two slices from adult or 4-wk-old animals were placed into open mouthed $15 \mathrm{ml}$ vials or Warburg flasks in order to measure the oxidation of taurine or its uptake. Slices were incubated in $2.0 \mathrm{ml}$ Tris-Ringer glucose or Krebs-Riger phosphate glucose buffer $(300 \mathrm{mOsm}, \mathrm{pH}$ 7.4 at $37^{\circ}$ under $100 \% \mathrm{O}_{2}$ at 7 liters (min) (12); $\mathrm{pH}$ measured before and after incubation changed $<0.1$ unit. After incubation, slices were removed, blotted, weighted on a Smith Roller torsion balance (47), and placed in $1.0 \mathrm{ml}$ distilled water, boiled for $5 \mathrm{~min}$. The supernate was recovered and counted in Aquasol (52) as described (7). Released $\mathrm{CO}_{2}$ was trapped in filter paper containing $50 \% \mathrm{KOH}$ and was counted in a water and Aquasol system (20).

The percent total tissue water was determined by drying tissue to constant weight at $110^{\circ}$ for $24-48 \mathrm{hr}$. The percent extracellular water was calculated from the distribution of poly $\left[{ }^{14} \mathrm{C}\right]$ ethylene glycol as described elsewhere (8). The intracellular water was derived from the percent extracellular water and total tissue water. The uptake of taurine was determined as previously described (20).

The incorporation of taurine into protein was ascertained by incubation of slices from newborn and adult animals in media for $180 \mathrm{~min}$ at $0.01 \mathrm{mM}$ taurine, removing, blotting, weighing, and homogenizing slices in $6 \%$ trichloroacetic acid (TCA). After centrifugation at $10,000 \times g$ for $30 \mathrm{~min}(45)$, the TCA insoluble fraction was removed, resuspended in glass distilled water, and an aliquot counted in the Aquasol system. Parallel samples from the supernate and tissue free incubation media containing TCA were also counted.

The accumulation of taurine by similar sized medulla was examined by a previously described method (20).

\section{ANALYTICAL}

Partition thin layer chromatography (TLC) on Eastman cellulose sheets using methanol: $30 \%$ ammonium hydroxide solvent $(95: 5)(20)$ was performed to confirm the presence of amino acids were located by ninhydrin staining. Quantitative measurement of taurine was performed as described previously $(10,49)$. Column eluates from urine or tissue samples contained only a single ninhydrin-staining spot by TLC analysis which had the same $R_{f}$ as a spot containing $99.7 \%$ of ${ }^{14} \mathrm{C}$-taurine counts, confirming that taurine was the only amino acid passing through the Dowex ion exchange column (48). In addition, only 0.1 and $0.03 \%$ of ${ }^{14} \mathrm{C} \alpha$ aminoisobutyrate and ${ }^{14} \mathrm{C}$ - $\alpha$-alanine counts were eluted through the $50-\mathrm{X} 12$ column.

Taurine concentrations, particularly in tissue and urine, were also determined by utilizing the reaction of the primary amine group of taurine with fluorescamine to form a fluorescent compound. The intensity of fluorescence is directly related to the concentration of taurine and a modification of previously described techniques was used $(23,24,36)$. Dried column eluates were resuspended in $2.0 \mathrm{ml}$ borate buffer, $\mathrm{pH} 9.1$, reacted with 0.5 $\mathrm{ml}$ fluorescamine $(10-15 \mathrm{mg} / \mathrm{ml})(50)$ and read in a fluorometer after $1 \mathrm{~min}$. Fluorescence is quite stable for at least $45 \mathrm{~min}$ and the optimal taurine concentration for measurement is $25-75 \mathrm{n}$ moles $/ 2.5 \mathrm{ml}$. Measurements were made in a G.K. Turner Fluorometer (51) using a taurine-free sample as a blank.

Creatinine in urine and plasma was determined by the method of von Pilsum (37).

Slice experiments were performed in triplicate and data comparison was made with Student's $t$ test.

\section{MATERIALS}

$\left[1-{ }^{14} \mathrm{C}\right]$ taurine (specific activity $56.4 \mathrm{Ci} / \mathrm{mole}$ ) and poly[1,2${ }^{14} \mathrm{C}_{2}$ ] ethylene glycol (specific activity $2.3 \mathrm{Ci} / \mathrm{mole}$ ) were purchased from New England Nuclear (52). Radiochemical purity was confirmed by one-dimensional TLC. Unlabeled amino acids were purchased from Sigma (53). All chemicals used to prepare media were reagent grade.

\section{RESULTS}

\section{IN VIVO STUDIES}

Newborn and 2-wk-old rat pups excreted more taurine in their urine than 4-wk-old and mature animals (Table 1). Taurinuria reached the normal range between the 2 nd and 4 th wk of life. Taurinuria in young animals occurred in the face of lower plasma taurine levels, thus, aminoaciduria was not the result of excessive taurine levels. The endogenous creatinine clearance rate in adult animals was $1.81 \pm 0.61 \mathrm{ml} \cdot \mathrm{min}-1$ (mean $\pm \mathrm{SE}, n=9), 2.45 \pm$ $0.41 \mathrm{ml} \cdot \mathrm{min}-1$ in 4 -wk-old $(n=10)$, and $0.27 \pm 0.31 \mathrm{ml} \cdot \mathrm{min}-1$ $(n=6)$ in 2-wk-old rats. Because timed urine collections were not possible in newborn animals, no clearance figures were determined. Nonetheless, taurinuria was evident from the more than 10 -fold increased concentration of taurine in terms of $\mu \mathrm{mole} / \mathrm{mg}$ urine creatinine. Because plasma taurine concentrations were comparable, the increased fractional reabsorption of taurine after 2 wk of age implies postnatal maturation of $\beta$-amino acid reclamation.

The taurine concentration in slices from the outer renal cortex was examined at each age (Table 2). The taurine content of in vivo renal cortex was higher in newborn tissue than in tissue of other ages. When the in vivo slice/plasma ratio expressed as $\mathrm{mmole} / \mathrm{ml}$ plasma $\mathrm{H}_{2} \mathrm{O}$ is examined, retention of taurine was evident in immature tissue where the distribution ratios were twice as high and significantly different from that in adult tissues (Fig. 1). This finding suggests that taurine may be retained in epithelial cells during transepithelial reclamation from the lumen to peritubular capillaries or uptake in the opposite direction. Alternately, taurine may be trapped within the lumen in tissue from immature animals, as suggested previously (10), thereby, resulting in higher distribution ratios.

\section{IN VITRO STUDIES}

\section{TISSUE WATER CONTENT}

Water spaces in rat kidney slices varied with age: 0.82 in the newborn; 0.791 in 2-wk tissues; 0.796 in 4-wk tissues; and 0.80 in 
Table 1. Concentration in plasma and urine and fractional reabsorption by kidney of taurine at different ages ${ }^{1}$

\begin{tabular}{|c|c|c|c|c|c|c|c|}
\hline & \multirow[b]{2}{*}{ NB } & \multicolumn{3}{|c|}{ Age of animal } & \multicolumn{3}{|c|}{$P$ values } \\
\hline & & 2 wk & $4 \mathrm{wk}$ & Adult & A vs. NB & A vs. 2 wk & A vs. $4 \mathrm{wk}$ \\
\hline $\begin{array}{l}\text { Plasma, } \mu \text { mole } \cdot \text { liter }^{-1} \text { plasma } \\
\mathrm{H}_{2} \mathrm{O}\end{array}$ & $\begin{aligned} 246.4 & \pm 42.8 \\
n & =6\end{aligned}$ & $\begin{aligned} 236.1 & \pm 56.0 \\
n & =7\end{aligned}$ & $\begin{aligned} 204.1 & \pm 27.5 \\
n & =11\end{aligned}$ & $\begin{aligned} 424.1 & \pm 88.6 \\
n & =8\end{aligned}$ & NS & NS & NS \\
\hline Urine, $\mu$ mole $\cdot \mathrm{mg}^{-1}$ creatinine & $\begin{aligned} 234.6 & \pm 126.8 \\
n & =4\end{aligned}$ & $\begin{aligned} 190.0 & \pm 36.4 \\
n & =7\end{aligned}$ & $\begin{aligned} 6.1 & \pm 3.9 \\
n & =4\end{aligned}$ & $\begin{aligned} 26.1 & \pm 8.2 \\
n & =10\end{aligned}$ & $<0.005$ & $<0.005$ & NS \\
\hline $\begin{array}{l}\text { Fractional reabsorption of tau- } \\
\text { rine }\end{array}$ & & $\begin{aligned} 0.536 & \pm 0.179 \\
n & =7\end{aligned}$ & $\begin{aligned} 0.982 & \pm 0.003 \\
n & =6\end{aligned}$ & $\begin{aligned} 0.961 & \pm 0.010 \\
n & =7\end{aligned}$ & & $<0.05$ & NS \\
\hline
\end{tabular}

${ }^{1}$ Urine was collected for $6 \mathrm{hr}$ as described in the text; $n$ refers to the number of experiments performed at each age. Fractional reabsorption was calculated from the formula: 1-(taurine clearance/creatinine clearance) where clearance is the amount excreted per minute divided by amount per $\mathrm{ml}$ plasma. Each value represents the mean $\pm \mathrm{SE}$ of determinations.

Table 2. Concentration of taurine in kidney cortex ${ }^{1}$

\begin{tabular}{|c|c|c|c|c|c|c|c|}
\hline & \multirow[b]{2}{*}{ NB } & \multirow[b]{2}{*}{$2 \mathrm{wk}$} & \multirow[b]{2}{*}{$4 \mathrm{wk}$} & \multirow[b]{2}{*}{ Adult } & \multicolumn{3}{|c|}{$P$ value } \\
\hline & & & & & NB vs. A & NB vs. 2 wk & NB vs. 4 wk \\
\hline $\begin{array}{l}\text { Slice homogenate } \mu \mathrm{mole}^{-\mathrm{g}^{-1}} \\
\text { wet weight } \\
\text { Slice homogenate (mean val- } \\
\text { ues) } \mu \text { mole } \mathrm{ml}^{-1} \text { ICF }\end{array}$ & $\begin{array}{c}15.89 \pm 0.57 \\
n=6 \\
25.63\end{array}$ & $\begin{array}{c}10.38 \pm 0.35 \\
n=7 \\
19.58\end{array}$ & $\begin{array}{c}9.77 \pm 0.73 \\
n=11 \\
18.79\end{array}$ & $\begin{array}{c}12.38 \pm 0.57 \\
n=9 \\
22.51\end{array}$ & $<0.01$ & $<0.001$ & $<0.001$ \\
\hline $\begin{array}{l}\text { Taurine distribution ratio } \\
\text { slice/plasma }\end{array}$ & $\begin{array}{c}77.21 \pm 15.31 \\
n=5\end{array}$ & $\begin{array}{c}52.63 \pm 8.10 \\
n=7\end{array}$ & $\begin{aligned} 57.26 & \pm 6.74 \\
n & =11\end{aligned}$ & $\begin{aligned} 28.81 & \pm 5.63 \\
n & =8\end{aligned}$ & $\begin{array}{l}\text { A vs. NB } \\
<0.05\end{array}$ & $\begin{array}{l}\text { A vs. } 2 \mathrm{wk} \\
<0.01\end{array}$ & $\begin{array}{l}\text { A vs. } 4 \mathrm{wk} \\
<0.02\end{array}$ \\
\hline Slice ICF/plasma & 124.53 & 99.30 & 110.11 & 52.38 & & & \\
\hline
\end{tabular}

' Homogenates of whole outer cortex and slices of outer cortex were prepared as described in the text. Each value in newborn rat pups represents the mean from a litter of newborn pups ( 9 or 10 pups), from 2-3 pups of age 2 wk and from one adult and 4-wk-old rat. Values represent the mean \pm SE.

adult cortex. The corresponding extracellular space was $0.182 \pm$ 0.018 (mean $\pm \mathrm{SD}, n=18)$ in newborn, $0.026 \pm 0.016(n=20)$ in 2-wk-old; $0.263 \pm 0.012(n=35)$ in 4-wk-old and $0.253 \pm 0.015$ $(n=40)$ in adult animal slices measured by incubating slices in polyethylene glycol for $30 \mathrm{~min}$. The derived intracellular water spaces were $64 \%$ in newborn; $59 \%$ in 2 -wk; $52 \%$ in 4 -wk; and $55 \%$ in adult tissue. Water space in newborn rat cortex slices after 240 min incubation in medium increased by only $2.4 \%$, an insignificant change. A comparable fall in the percent intracellular fluid was also found, also insignificant. Thus, there was no expansion of the water space of the slice during prolonged incubation.

\section{METABOLISM OF TAURINE}

Conversion of taurine to ${ }^{14} \mathrm{CO}_{2}$ at each age was less than $1 \%$ of the counts taken up by the slices. More than $90 \%$ of the radioactivity found in the supernate after homogenization of incubated tissues proved to have the same $R_{f}$ as taurine when subjected to ascending TLC. The incorporation of counts into the TCA insoluble fraction was less than $0.008 \%$ at all ages. Thus, taurine appears to be inert in renal tissue and is not incorporated into protein within the cell to any extent.

\section{TIME COURSE OF UPTAKE}

Taurine uptake by cortex slices reached steady state after 45 min at 1.0 and $20.0 \mathrm{mM}$ external medium concentration in adult kidney (Fig. 2, 3, 4), but continued up to $120 \mathrm{~min}$ at 0.01 and 0.1 $\mathrm{mM}$. Further, taurine was accumulated against a chemical distribution ratio, with an isotopic distribution ratio of $>20.0$ at a medium concentration of $0.01 \mathrm{mM}$, indicating active uptake. Uptake against a concentration gradient also occurred in immature rat cortex at $0.01,0.1$, and $1.0 \mathrm{mM}$, but did not exceed a distribution ratio of unity in 2-wk and newborn cortex after incubation in taurine at 20 and $60 \mathrm{mM}$. Examination of uptake with time at $0.01,0.1,1.0$, and $20 \mathrm{mM}$ reveals that accumulation is still continuing after $120 \mathrm{~min}$ in newborn, 2-wk, and 4-wk cortex. At $0.01 \mathrm{mM}$ in newborn tissue steady state accumulation was not achieved even after $240 \mathrm{~min}$ and the distribution ratio of 52 was 2.5 fold increased over adult cortex slices (Fig. 2).

Uptake at $0.1 \mathrm{mM}$ was significantly higher in immature tissue than in adult cortex, $\mathrm{p}<0.01,<0.01$, and $<0.001$ in 4 -wk, 2 -wk, and newborn slices, respectively, at $240 \mathrm{~min}$ (Fig. 3). At $1.0 \mathrm{mM}$ taurine, the final steady-state distribution ratio was 4.0 , but adult cortex slices achieved this level at $45 \mathrm{~min}$, slices from 4 wk-old at $90 \mathrm{~min}$, from 2-wk-old animals at $120 \mathrm{~min}$ and newborn tissue did not achieve this level until $240 \mathrm{~min}$ demonstrating a maturational precession of uptake (Fig. 4).

\section{PH OPTIMUM FOR TRANSPORT}

Taurine uptake at $0.01 \mathrm{mM}$ and $1.0 \mathrm{mM}$ in adult cortex slices was maximal at $\mathrm{pH} 7.4$; a similar pattern was seen in 4-wk-old cortex slices (Fig. 5). In contrast, uptake in slices from newborn and 2-wk-old animals was maximal at $\mathrm{pH} 7.6-8.4$. Below a $\mathrm{pH}$ of 6.8 , there was a marked reduction in uptake at the four ages.

\section{TEMPERATURE SENSITIVITY}

Net slice accumulation of taurine was stimulated less by elevation of incubation temperature from 22 to $37^{\circ}$ in the 4-wk and adult compared to the newborn at $0.01 \mathrm{mM}$ (Table 3). This response may be related to greater efflux in the adult (shown in the companion paper). Net uptake of taurine at 1.0 and $20.0 \mathrm{mM}$ was stimulated to the same extent in slices from animals of each age. In each instance, uptake was lower at 22 than $37^{\circ}$, in contrast to the situation for cysteine uptake (27).

\section{INFLUENCE OF INCREASED MEDIUM POTASSIUM LEVELS}

An external $\mathrm{K}+$ concentration of $8-12 \mathrm{mEq} /$ liter was optimal to support $\alpha$-amino-isobutyrate and glycine accumulation by kid- 


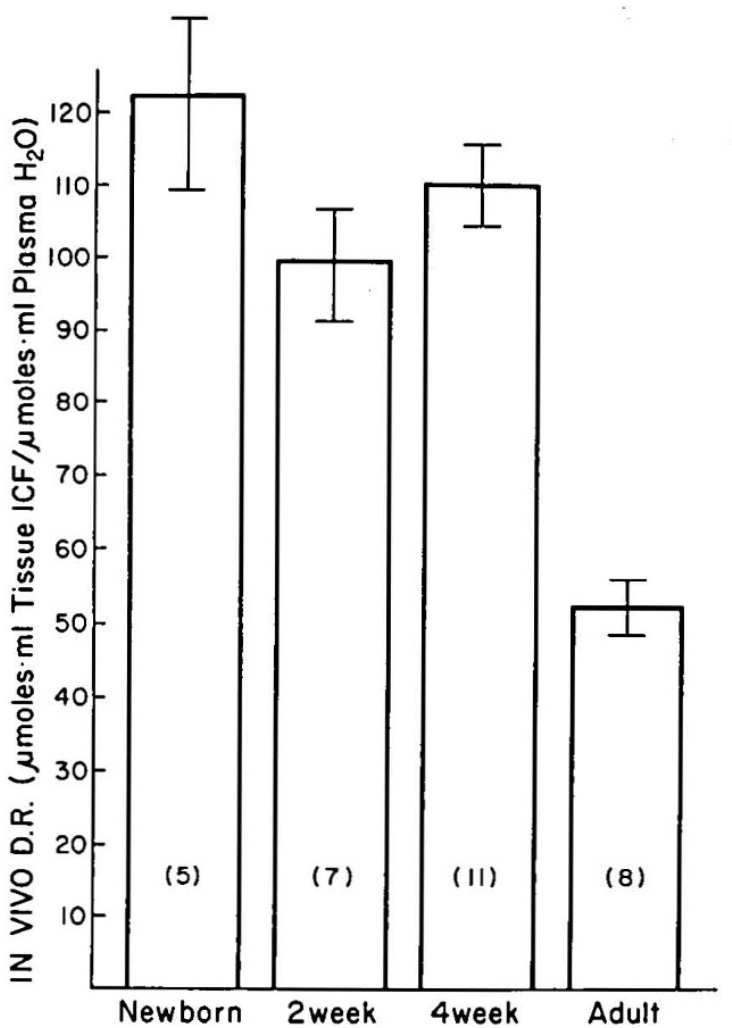

Fig. 1. Distribution of taurine in cortex slices to taurine in plasma from animals of the ages shown. Taurine concentrations are determined by chemical methods using either an amino acid analyzer (29) or the reaction of the amino group of taurine with fluorescamine (24). Each bar represents the mean $\pm \mathrm{SE}$ of values ascertained when parallel determinations of tissue and plasma are available. The distribution ratio in adult tissue is significantly lower than that found in newborn, 2-wk, and 4-wk-old animals.

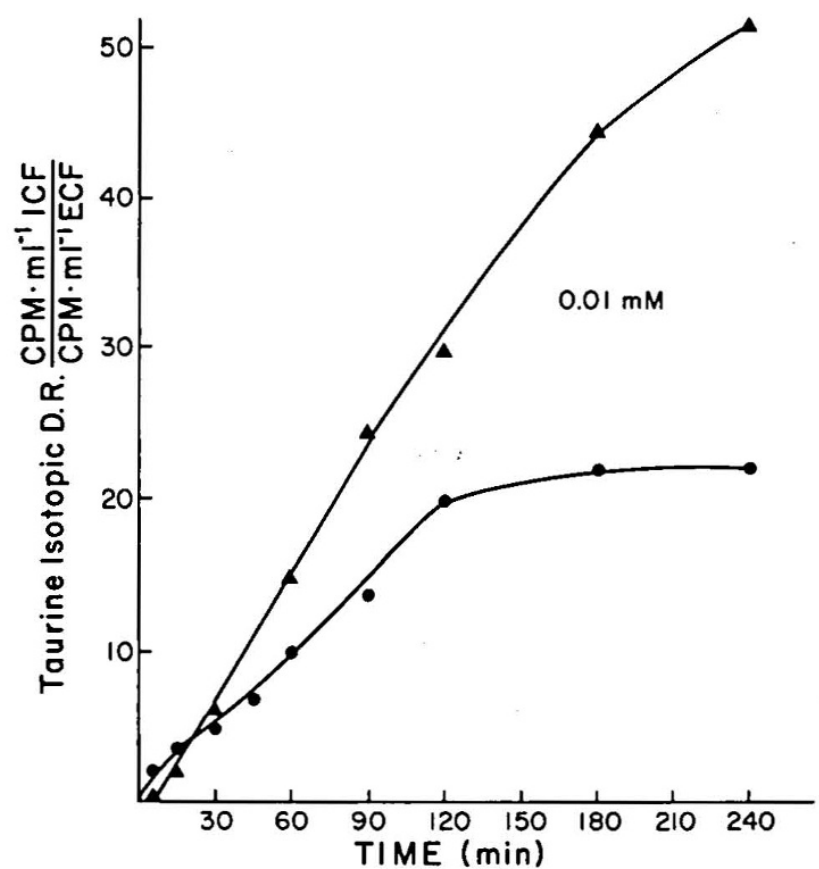

Fig. 2. Time course for uptake of $\left[1^{-14} \mathrm{C}\right]$ taurine by rat kidney outer cortex slices at $37^{\circ} \mathrm{C}$ in $\mathrm{pH} 7.4$ Tris buffer by tissue of rats different ages at $0.01 \mathrm{mM}$. Each point is the mean of 30 flasks. Symbols: $\boldsymbol{\bullet}$, adult; $\boldsymbol{\Delta}$, newborn. The conversion of taurine after uptake of $\mathrm{CO}_{2}$ or other labeled material is $<1 \%$ of the total uptake.

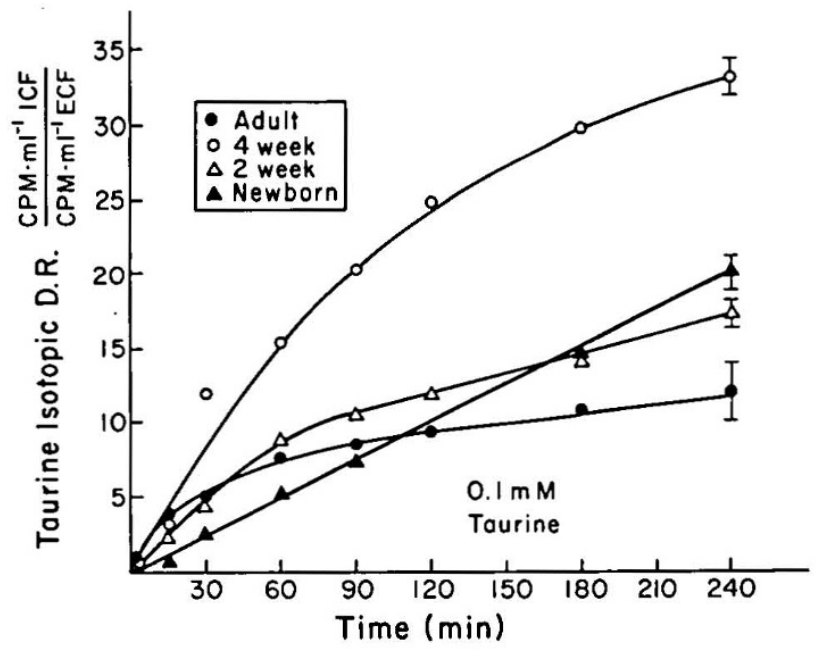

Fig. 3. Time course for uptake of $\left[1^{-14} \mathrm{C}\right]$ taurine by rat kidney outer cortex slices of the ages shown in the insert. Slices were incubated in Tris buffer $\mathrm{pH} 7.4$ at initial taurine concentration of $0.1 \mathrm{mM}$ and each point represents the mean of 15 flasks. The values at $240 \mathrm{~min}$ represent the mean $\pm \mathrm{SE}$ and uptake by slices from immature animals is significantly different from uptake by adult rat slices as described in the text.

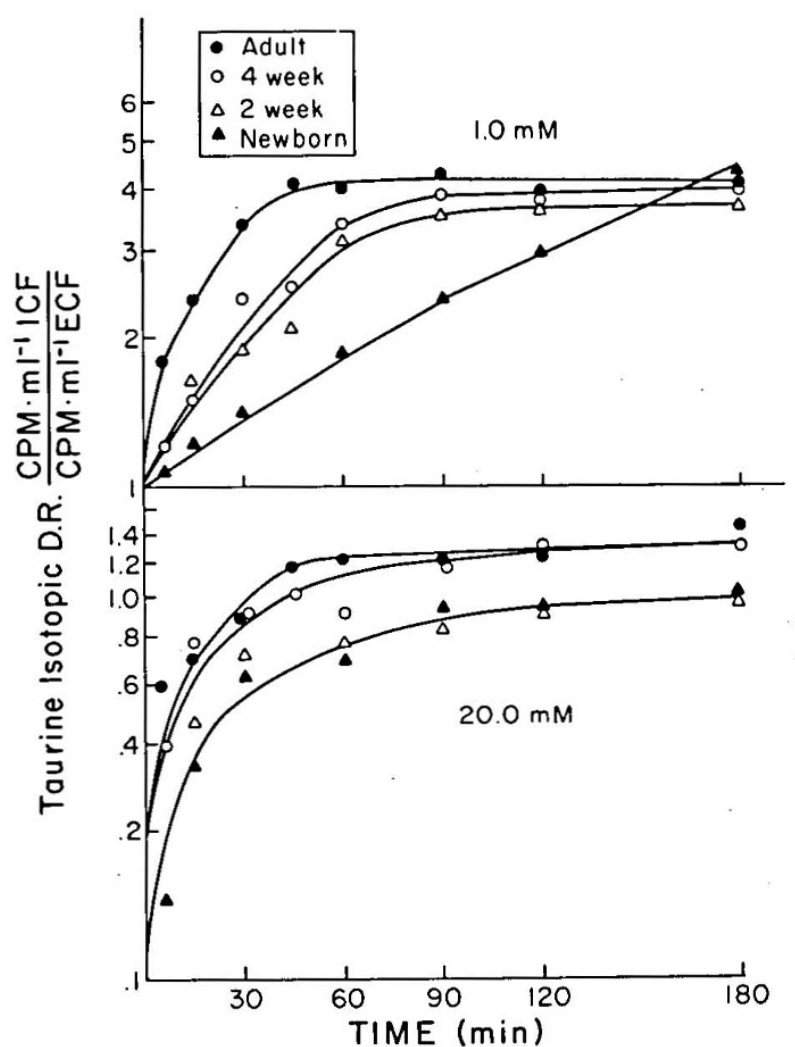

Fig. 4. Time course of uptake of $\left[1^{-14} \mathrm{C}\right]$ taurine by cortex slices in medium at 1.0 and $20.0 \mathrm{mM}$ taurine. Each point represents the mean of 15 flasks and slices were incubated in $\mathrm{pH}$ 7.4 Tris buffer for the times shown. The symbols for each age are shown in the insert.

ney cortex (14). The influence of increasing potassium levels in the medium, achieved by substitution of $\mathrm{KCl}$ for $\mathrm{NaCl}$ so as to maintain isosmolality, is shown in Fig. 6. At $0.01 \mathrm{mM}$ taurine, maximal uptake occurred at an external potassium concentration of $10-15 \mathrm{mEq} /$ liter in both adult and newborn tissue. At $2.0 \mathrm{mM}$ taurine, accumulation by adult tissue was maximal at $5-15 \mathrm{mEq}$ / liter. No changes in uptake by immature animal cortex slices were found over the range $0-45 \mathrm{mEq} / \mathrm{liter}$ in both adult and newborn 


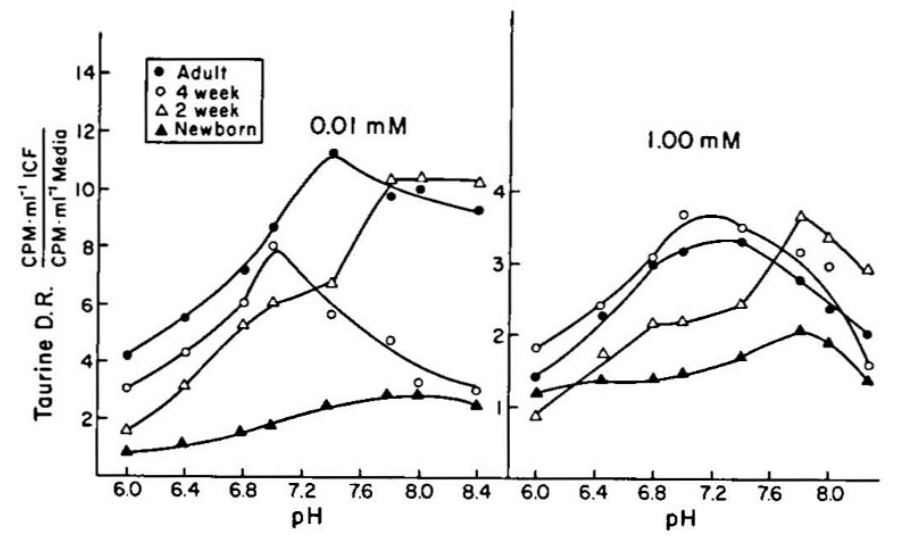

Fig. 5. Distribution ratios of $\left[1^{-14} \mathrm{C}\right]$ taurine incubated in Tris buffer over the $\mathrm{pH}$ range 6.0-8.4. Outer cortex slices from animals of the ages shown in the insert were incubated at $37^{\circ}$ in either 0.01 or $1.0 \mathrm{mM}$ taurine for $\mathbf{4 5}$ min. Each point represents the mean of 6 flasks.

Table 3. Influence of temperature of isotopic distribution ratio in rat kidney cortex slices from animals of different ages ${ }^{1}$

\begin{tabular}{clrrc}
\hline & & \multicolumn{3}{c}{ Distribution ratio } \\
\cline { 3 - 5 } Taurine concentration & Age of animal & $22^{\circ}$ & $37^{\circ}$ & $37^{\circ} / 22^{\circ}$ \\
\hline \multirow{2}{*}{$0.1 \mathrm{mM}$} & Adult & 6.9 & 11.2 & 1.6 \\
& $4 \mathrm{wk}$ & 2.9 & 6.0 & 2.1 \\
& Newborn & 2.0 & 9.0 & 4.5 \\
& & & & \\
\multirow{2}{*}{$1.0 \mathrm{mM}$} & Adult & 2.1 & 4.1 & 2.0 \\
& $4 \mathrm{wk}$ & 1.4 & 3.4 & 2.4 \\
& Newborn & 1.0 & 2.0 & 2.0 \\
& & & & \\
& Adult & 0.7 & 1.3 & 1.9 \\
& $4 \mathrm{wk}$ & 0.6 & 1.0 & 1.7 \\
& Newborn & 0.8 & 0.8 & 1.0 \\
\hline
\end{tabular}

'Distribution ratio refers to the CPM ml ${ }^{-1}$ tissue ICF/CPM ml medium. Incubation for $45 \mathrm{~min}$ in Tris Ringers glucose medium at $\mathrm{pH} 7.4$ under $\mathrm{O}_{2}$ at the specified temperature. The value given the mean from six flasks at each concentration.

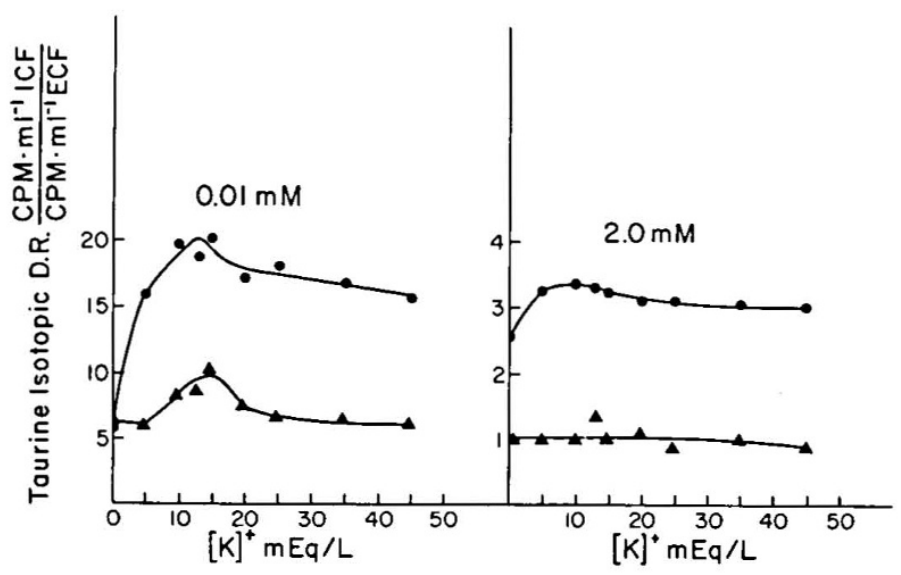

Fig. 6. Distribution ratios of $\left[1^{-14} \mathrm{C}\right]$ taurine incubated in Tris buffer containing the potassium concentrations shown on the abscissa. Outer cortex slices from newborn and adult animals were incubated at $37^{\circ}$ in either 0.01 or $2.0 \mathrm{mM}$ taurine for $60 \mathrm{~min}$. Each point represents the mean of 6 flasks. Potassium chloride was substituted for sodium chloride so as to maintain isosmolality. Symbols: newborn, $\boldsymbol{\Delta}$; adult $\boldsymbol{\bullet}$. tissue. At $2.0 \mathrm{mM}$ taurine, accumulation by adult tissue was maximal at $5-15 \mathrm{mEq} /$ liter. No changes in uptake by immature animal cortex slices were found over the range $0-45 \mathrm{mEq} / \mathrm{liter}$ external medium potassium.

\section{TAURINE ACCUMULATION BY RENAL MEDULLA SLICES}

Contamination of cortex slices with medullary tissue is of obvious concern in newborn rat kidney since the cortex is thin. The uptake of taurine at $0.01 \mathrm{mM}$ in medullary slices was substantially less than the uptake by the outermost slice of cortex. Therefore, any contamination of cortex slices by medulla would tend to result in lower distribution ratio values and minimize the higher distribution ratios found in immature cortex and those found in adult cortex. It is unlikely that medullary contamination could account for the different properties of taurine accumulation by tissue from immature animals.

\section{DISCUSSION}

Immediately after birth, the newborn mammalian kidney must regulate water, ion and organic solute reabsorption, and nitrogenous waste produce excretion, a task formerly carried out by the placenta. Over the first weeks to months of life, a distinct and complex pattern of the maturation of renal function takes place (21). Indeed, nearly all the characteristics of the immature kidney are unique when compared to those at any other period of life. Marked increases in total renal blood flow, glomerular filtration rate and outer cortex nephron perfusion, decreased intrarenal vascular resistance, enhanced capacity to excrete a water load, and increased concentrating capacity characterize this newborn period (33). The neonates of nearly all mammalian species, including man, have reduced net transtubular reabsorption of many amino acids leading to a "physiologic" neonatal aminoaciduria, but this urinary amino acid loss disappears with maturation $(6,27,30)$. In both human and rat infants, excretion of glycine, imino acids (proline and hydroxyproline), dibasic amino acids, and taurine are especially prominent $(2-4,6,26,27,39)$.

Three groups of investigators utilized the slice technique in vitro to delineate the ontogeny of amino acid transport. Weber and Cairns (38-40) examined the active accumulation of glycine, leucine, lysine, glutamate, and $\alpha$-AIB by rat cortex slices, so as to define the maturation of each of the major $\alpha$-amino acid classes. Lower distribution ratios were found after $120 \mathrm{~min}$ for glycine, leucine, and glutamic acid, but lysine and $\alpha$-AIB accumulation were still increasing in a linear fashion after this interval. Segal and Smith $(31,32)$ showed that lysine uptake was similar in neonatal and adult cortex slices, but cystine uptake was decreased and did not reach adult levels until age 2-wk. However, lysine accumulation was much less sodium-dependent than in adult tissue; cystine accumulation was actually more sodium-dependent. Cystine accumulation was similar at all ages. Baerlocher $e$ t al. (24) found a complex pattern of emerging transport systems for glycine and iminoacid reabsorption with ontogeny (30). Prolinuria and hydroxyprolinuria disappeared after 7 days, but glycinuria persisted for $3 \mathrm{wk}$. The slice steady state levels of glycine, proline, and hydroxyproline were higher in newborn tissue upon longer incubation. Higher tissue levels of amino acid $(2-4,6,26,27,38$ 40 ) in the face of neonatal aminoaciduria may seem puzzling, but two other findings may explain this paradox. First, the initial rate of glycine or proline uptake at lower concentrations was slower in immature tissue. Second, greater retention of amino acid within the slice could be related to decreased efflux of these substances across the antiluminal membrane back into media in newborn tissue $(1,3,26,32,39)$. There, investigators showed that the low $\mathrm{Km}$, high affinity, low capacity transport system for proline first appeared at age $2 \mathrm{wk}$ and for glycine at $3 \mathrm{wk}$, but that the shared system for glycine and both imino acids was present at birth. Using another strain of rat, Segal and Smith (31) were unable to confirm these age-related differences in the appearance of trans- 
port processes; both the low $\mathrm{Km}$ and high $\mathrm{Km}$ uptake systems were intact by age 5 days.

To date, the ontogeny of the $\beta$-amino acid transport system has not been examined. This study demonstrates that neonatal Sprague-Dawley rats have taurinuria, disappearing after 2 wk of age. The sizable increase in glomerular filtration rate occurring between age 2 and 4 wk coupled with the increased net reabsorption of taurine implies that the $\beta$-amino acid transport system undergoes maturation during this time. We examined the cortex slice accumulation of taurine both in vivo and in vitro in order to further define this process of maturation.

Taurine uptake was active because it occurred against a concentration gradient. This amino acid is not further metabolized or incorporated into protein by kidney cortex tissue of any animal age. Tissue taurine concentrations and the in vivo distribution ratios parallel the in vitro ratios in that higher steady state values were found in tissue from immature animals at physiologic and subphysiologic taurine concentrations $(<0.4 \mathrm{mM} /$ liter $)$. The steady state accumulation ratio was higher in immature cortex slices at $<0.4 \mathrm{mM}$ and lower than adult ratios at $>0.4 \mathrm{mM}$. The initial rate of uptake, efflux kinetics, and sodium dependency of accumulation will be discussed in the accompanying paper, but the higher in vivo taurine concentration found in newborn rat cortex distribution ratios found in tissue from immature animals anticipates the finding of decreased efflux. The incorporation of [35S]-taurine into neonatal mouse kidney showed a similar pattern: slower rate of uptake, but a higher distribution ratio in immature tissue (22). The finding of aminoaciduria in the face of higher accumulation ratios may be the result of decreased efflux, as suggested by Segal and Smith (31) or by the maturation of $\alpha$ luminal transport mechanism at a time later than the antiluminal transport systems. Furthermore, the luminal membrane permeability to taurine decreased in immature animals, more of this $\beta$ compound could be retained within the luminal pool and higher in vivo distribution ratios and more aminoaciduria would occur, as suggested in the mouse by Chesney et al. (10). This latter hypothesis can only be tested by examining the kinetics of taurine uptake by isolated luminal membranes at various ages.

The dependence of net taurine uptake pH showed some differences between adult and immature tissue. The $\mathrm{pH}$ optima was higher in newborn and 2-wk-old animal cortex. Temperature elevation from $22-37^{\circ}$ did not increase the distribution ratio in adult tissue as much as in newborn tissue at low substrate concentrations, but no differences in temperature dependent accumulation were noted at higher concentrations.

The pattern of emergence of the transport systems for taurine uptake and efflux at various ages and the sodium and oxygen dependency of accumulation are examined in the accompanying paper.

\section{REFERENCES AND NOTES}

1. Baerlocher, K. E.: Developmental aspects of amino acid transport. In: F. A Hommes and C. J. Van DenBerg: Inborn Errors of Metabolism, p. 143-176 (Academic Press, London, 1973).

2. Baerlocher, K. E., Scriver, C. R., and Mohyuddin, F.: Ontogeny of iminoglycine transport in mammalian kidney. Proc. Natl. Acad. Sci., 65: 1009 (1970).

3. Baerlocher, K. E., Scriver, C. R., and Mohyuddin, F.: The ontogeny of amino acid transport in rat kidney. I. Effect on distribution ratios and intracellula metabolism of proline and glycine. Biochim. Biophys. Acta, 249: 353 (1971).

4. Baerlocher, K. E., Scriver, C. R., and Mohyuddin, F.: The ontogeny of amino acid transport in rat kidney. II. Kinetics of uptake and effect of anoxia. Biochim. Biophys. Acta, 249: 364 (1971).

5. Blake, R. L., Grillo, R. V., and Russell, E. S.: Increased taurine excretion in hereditary hyperprolinemia of the mouse. Life Sci., 14: 1285 (1974).

6. Brodehl, J., and Gellisen, K.: Endogenous renal transport of free amino acids in infancy and childhood. Pediatrics, 42: 395 (1968).

7. Chesney, R. W., and Jax, D. K.: Heterogeneity of the $\beta$-amino preferring transport in rat kidney cortex. Biochim. Biophys. Acta, $466: 84$ (1977).

8. Chesney, R. W., Jax, D. K., Mohyuddin, F., and Scriver, C. R.: In vitro use of polyethylene $\left(1,2^{14} \mathrm{C}\right)$-glycol to measure extracellular space in renal cortex slices. Renal Physiol., (in press, 1979).

9. Chesney, R. W., Jax, D. K., Scriver, C. R., and Mohyuddin, F.: Taurine transport in mammalian kidney. In: A. Barbeau and R. J. Huxtable: Taurine and
Neurological Disorders, p. 73-93 (Raven Press, New York, 1978).

10. Chesney, R. W., Scriver, C. R., and Mohyuddin. F.: Localization of the membrane defect in transepithelial transport of taurine by parallel studies in vivo and in vitro in hypertaurinuric mice. J. Clin. Invest., 57: 183 (1976).

11. Dantzler, W. H., and Silbernagel, S.: Renal tubular reabsorption of taurine, $\alpha-$ aminobutyric acid (GABA) and $\beta$-alanine studied by continuous microperfusion. Pfluegers. Arch., 367: 123 (1976).

12. Datta, S. P., and Herris, H.: Urinary amino acid patterns of some mammals. Ann. Eugen., 18: 107 (1953-54).

13. Eisenbach, B. M., Weise, M., and Stolte, H.: Amino acid reabsorption in the rat nephron. Pfluegers. Arch., 357: 63, (1975).

14. Fox, M., Thier, S., Rosenberg, L. E., Kiser, W., and Segal, S.: Evidence against a single renal transport defect in cystinuria. N. Engl. J. Med., 270: 556 (1964).

15. Gaull, G. E., Rassin, D. K., Raiha, N. C. R., and Heinonen, K. J.: Milk protein quantity and quality in low birth weight infants. III. Effects on sulfur containing amino acids in plasma and urine. J. Pediatr., 90: 348 (1977).

16. Goldman, H., and Scriver, C. R.: A transport system in mammalian kidney with preference for $\beta$-amino compounds. Pediatr. Res., $1: 212$ (1967).

17. Harris, H., and Searle, A. G.: Urinary amino acids in mice of different genotypes. Ann. Eugen., 17: 165 (1973).

18. Jacobson, J. G., and Smith, L. H.: Biochemistry and physiology of taurine and taurine derivatives. Physiol. Rev., 48: 424 (1968).

19. Lingard, J. N., Turner, B., Williams, D. B., and Young, J. A.: Endogenous amino acid clearance by the rat kidney. Aust. J. Exp. Biol. Med. Sci., 52: 687 (1974).

20. Mohyuddin, F., and Scriver, C. R.: Amino acid transport in mammalian kidney: multiple systems for imino acids and glycine in rat kidney. Am. J. Physiol., 219: 1 (1970).

21. Nash, M. A., and Edelmann, C. M., Jr.: The developing kidney. Immature function or inappropriate standard. Nephron, 11: 71 (1973).

22. Oja, S. S., Lehtinen, I., and Lahdesmaki, P.: Taurine transport rates between plasma and tissues in adult and 7-day-old mice. Quart. J. Exp. Physiol., 61: 133 (1976)

23. Orr, H. T., Cohen, A. I., and Lowry, O. H.: The distribution of taurine in the vertebrate retina. J. Neurochemistry, 26: 609 (1976).

24. Roche Diagnostics, Division of Hoffman-La Roche, Inc. Fluorescamine package insert and instructions.

25. Rosenberg, L. E., Blair, A., and Segal, S.: Transport of amino acids by slices of rat kidney cortex. Biochim. Biophys. Acta, 54: 479 (1961).

26. Scriver, C. R., Baerlocher, K. E., Mackenzie, S., and Mohyuddin, F.: Ontogeny of iminoglycine transport in renal tubules and glomeruli. 4th International Congress of Nephrology, Stockholm, 1: 50 (1969).

27. Scriver, C. R., and Bergeron, M.: Amino acid transport in kidney. The use of mutation to dissect membrane and transepithelial transport. In: W. L. Nyhan: Heritable Disorders of Amino Acid Metabolism, p. 515-592 (John Wiley and Sons, New York, 1974).

28. Scriver, C. R., Clow, C. L., and Lamm, P.: Plasma amino acids: screening, quantitation, and interpretation. Am. J. Clin. Nutr., 24: 876 (1971).

29. Scriver, C. R., Davies, E., and Lamm, P.: Accelerated selective short column chromatography of neutral and acidic amino acids on a Beckman-Spinco analyzer, modified for simultaneous analysis of two samples. Clin. Biochem., 1: 179 (1968).

30. Scriver, C. R., and Rosenberg, L. E.: Amino Acid Metabolism And Its Disorders, p. 46-51 (W. B. Saunders, Philadelphia, 1973).

31. Segal, S., and Smith, I.: Delineation of cystine and cysteine transport systems in rat kidney cortex by developmental patterns. Proc. Nat. Acad. Sci., 63: 926 (1969).

32. Segal, S., and Smith, I.: Delineation of separate transport systems in rat kidney cortex for L-lysine and L-cystine by developmental patterns. Biochim. Biophys. Res. Comm., 35: 771 (1969).

33. Spitzer, A.: Renal physiology. Ped. Clin. N. Am. 18: 377 (1971).

34. Sturman, J. A.: Taurine in nutrition. Comprehens. Ther., 3: 59 (1977).

35. Sturman, J. A., Rassin, D. K., and Gaull, G. E.: Taurine in developing rat brain: transfer of $\left.{ }^{35} \mathrm{~S}\right]$ taurine to pups via the milk. Pediatr. Res., 11: 28 (1977).

36. Udenfriend, S., Stein, S., Bohlen, P., Dairman, W., Lensgruber, W., and Weigler, R.: Applications of fluorescamine. A new reagent for assay of amino acids, peptides, proteins, and other primary amines in the picomole range. Science, 178: 871 (1972).

37. Von Pilsum, J. F.: Picric acid method: Lloyd's reagent modification for creatinine, in blood serum, and urine. Methods Biochem., 7: 200 (1959).

38. Weber, W. A.: A comparison of the efflux rate for AIB from kidney cortex slices of mature and newborn rats. Can. J. Phys. Pharm., 46: 765 (1968).

39. Weber, W. A.: Amino acid excretion patterns in developing rats. Can. J. Phys. Pharm., 45: 867 (1967).

40. Weber, W. A., and Cairns, J. A.: A comparison of the amino acid concentrating ability of the kidney cortex of newborn and mature rats. Can. J. Physiol. Pharm., 46: 165 (1968)

41. Weeden, R. P.: Section freeze-dry autoradiography of P-aminohippuric acid and amino acid transport in the mammalian tubule. In: M. D. Blaufox and J. L. Funck-Brentano: Radionuclides in Nephrology, p. 209 (Grune \& Stratton, New York, 1972).

42. Weeden, R. P., and Weiner, B.: The distribution of P-amino-hippuric acid in rat kidney slices. II. Depth of uptake. Kidney Int., 3: 205 (1973).

43. Rats are obtained from Holtzman Co., Madison, WI. or from the ARS SpragueDawley Co., Fitchburg, WI.

44. Metabolic cages were obtained from Sargent Welch Scientific Co., $7300 \mathrm{~N}$. Lunder Ave., Skokie, IL 60076.

45. Centrifugation was performed in a Sorvall RCB-2 using a fixed angle head at 
$4^{\circ} \mathrm{C}$. The centrifuge was obtained from Sorvall Co., Norwark, CT.

46. Media consists of $\mathrm{NaCl} 124.2 \mathrm{mEq} / \mathrm{liter}, \mathrm{KCl} 5.0 \mathrm{mEq} / \mathrm{liter}, \mathrm{CaCl}_{2} 2.5 \mathrm{mEq} /$ liter; $\mathrm{Mg} \mathrm{SO}_{4} 7 \mathrm{H}_{2} \mathrm{O} 1.2 \mathrm{mEq} /$ liter; Dextrose $5.0 \mathrm{mM} /$ liter; and Tris $\mathrm{HCl} \mathrm{pH}$ $7.427 .4 \mathrm{mEq} / \mathrm{liter}$.

47. Purchased from Arthur Thomas Co., Philadelphia, PA.

48. Ion exchange was performed on a $4.5 \times 1.0 \mathrm{~cm}$ Dowex 50-X12 resin (200-400) mesh in the $\mathrm{H}^{+}$form well washed before use. Sigma Chemical Co., St. Louis, MO.

49. Beckman Instruments, Inc., Spinco Division, Palo Alto, CA.

50. Fluorescamine is obtained from Hoffman-LaRoche, Nutley, NJ or Pierce Chem. Co., Box 117, Rockford, IL 61105.

51. The G. K. Turner, Co., 2524 Pulgas Avenue, Palo Alto, CA. 94303.

52. New England Nuclear Corp., Boston, MA.

Copyright (C) 1979 International Pediatric Research Foundation, Inc. 0031-3998/79/1307-0854\$02.00/0
53. Sigma Chemical Co., St. Louis, MO.

54. The authors acknowledge helpful discussions with Dr. Aaron Friedman, A. F. Harper, and D. Simpson and the expert typing of K. Chenoweth-Corby.

55. This research was supported by funds from the Graduate School Research Committee of the University of Wisconsin. The Jessie E. Whitman Bequest and grant AM19489 from the National Institute of Arthritis, Metabolic and Digestive Diseases.

56. Requests for reprints should be addressed to: R. W. Chesney, M. D., The Pediatric Renal Disease Laboratory, The University of Wisconsin Center for Health Sciences, 1300 University Avenue, Madison, WI 53706, USA.

57. Received for publication April 11, 1978.

58. Accepted for publication July 27, 1978. 